\title{
Albumin-binding proteins on the surface of the Streptococcus milleri group and characterization of the albumin receptor of Streptococcus intermedius $\mathbf{C 5}$
}

\author{
M. D. P. Willcox, ${ }^{*}$ M. Patrikakis, C. Y. Loo and K. W. KNox \\ Institute of Dental Research, United Dental Hospital, Sydney, NSW 2010, Australia
}

(Received 16 February 1993; revised 26 April 1993; accepted 5 May 1993)

\begin{abstract}
Members of the Streptococcus milleri group (SMG) that react with Lancefield group C antisera were shown to bind large amounts of albumin although there was no direct relation between these two properties as polyclonal antisera to Lancefield group $C$ antigen did not prevent the binding of albumin. There was a specificity for albumin binding, with albumin from man, monkeys, cat, dog and mouse being bound to a greater degree than albumin from cow, horse, goat or rabbit. Gold-labelled albumin was shown to be located close to the surface of strains by

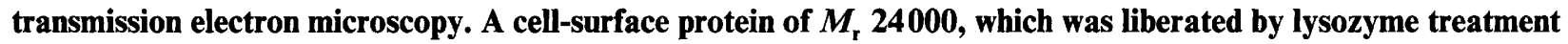
of cells, was shown to be the cell-surface receptor on Streptococcus intermedius $\mathbf{C 5}$. The receptor was physically dissimilar from protein G, an albumin- and IgG-binding protein of 'large-colony' Lancefield group C and G streptococci.
\end{abstract}

\section{Introduction}

The Streptococcus milleri group (SMG) is composed of three related species, Streptococcus anginosus, Streptococcus intermedius and Streptococcus constellatus (Whiley \& Hardie, 1989). Members of all species have been isolated from the human oral cavity, which is considered to be their environmental niche (Mejàré \& Edwardsson, 1975), and where they have been implicated in dental caries (Drucker \& Green, 1978) and dental abscesses (Williams et al., 1983). Their occurrence at other body sites indicates that they may be commensal (Ruoff, 1988), though their isolation from severe suppurative infections in many organs in the human body, including the liver (Moore-Gillon et al., 1981), the central nervous system and from patients with infective endocarditis (Gossling, 1988), indicates their pathogenic potential. To this extent it has been realized in recent

\footnotetext{
* Author for correspondence. Present address: Cooperative Research Centre for Eye Research and Technology, University of New South Wales, PO Box 1, Kensington, NSW 2031, Australia. Tel. 2931 0213; fax, 29310202.
}

Abbreviations: BHI, brain heart infusion; POW, Prince of Wales Hospital; SMG, Streptococcus milleri group; SLS, sodium lauroylsarcosinate; PBST, phosphate buffered saline containing Tween 20; LTA, lipoteichoic acid. years that SMG strains may be 'unrecognized pathogens' (Ruoff, 1988). Most of the strains possess Lancefield group antigen A, C, F or G (Whiley et al., 1990; Gossling, 1988) and several investigations have been made into the relation between the 'large-colony' Lancefield group A, C or G streptococci (particularly Streptococcus equi and Streptococcus dysgalactiae) and the 'minute-colony' SMG, especially as both colony types can be isolated from similar sites (Lawrence $e t$ al., 1985; Cimolai et al., 1988).

Information on the pathogenic determinants of the SMG is limited. However, certain strains do have the capacity to bind fibronectin, fibrinogen, albumin (Willcox \& Knox, 1990; Willcox et al., 1992), laminin (Switalski et al., 1987), $\beta_{2}$-microglobulin (Ericson et al., 1980 ) and/or plasminogen (Ullberg et al., 1989). Studies on the binding of albumin and IgG by large-colony streptococci of Lancefield groups $\mathrm{C}$ and $\mathrm{G}$ have demonstrated that the cell-surface molecule protein $\mathrm{G}$ is responsible for the binding of both proteins and also $\alpha_{2}-$ macroglobulin by some strains (Lämmler et al., 1988; Wideback et al., 1982). The albumin receptors from the various species have been shown to bind specific albumins; for example, $S$. dysgalactiae strains (group C strains) show specificity for bovine serum albumin (Wideback \& Kronvall, 1982; Raeder et al., 1991). To date at least five different types of albumin receptor have 
been described based on their ability to bind albumin from different animal species. It has also been proposed that lipoteichoic acid, a common amphiphile associated with the cell wall of most species of streptococci, can bind to albumin (Simpson et al., 1980) and may account for the low-affinity binding levels seen with many streptococcal cells.

Analogies with the interaction of other streptococci with mammalian proteins point to possible pathogenic functions for albumin binding. The binding of albumin to group A streptococci increases phagocytosis but not intracellular killing (Wagner et al., 1986). It has been demonstrated that there may be some protective advantage in abscess-producing bacteria being phagocytosed by abscess-derived neutrophils, which are inefficient at killing bacteria (Finlay-Jones et al., 1991).

The aim of the present investigation was to examine strains within the SMG for their ability to bind albumin from several animal species, to localize the receptor for albumin by electron microscopy, to characterize the receptor on the surface of a strain and to determine whether the receptor was similar to protein $\mathrm{G}$.

\section{Methods}

Bacterial strains and growth conditions. Table 1 shows the strains used and their site of isolation. The SMG were kindly supplied by Dr J. Tappsell, Prince of Wales Hospital, Sydney (POW strains) and Dr K. Ruoff, Massachusetts General Hospital, Boston, USA. Largecolony group C (Streptococcus dysgalactiae) and G strains were the kind donation of Professor L. Björck, University of Lund, Sweden, and were included as positive controls for albumin binding and DNA-DNA hybridizations. Staphylococcus aureus strain STA3 was from our freeze-dried culture collection and was included in the study as a negative control in DNA-DNA dot-blot hybridizations. Strains were stored at $-70{ }^{\circ} \mathrm{C}$ in $30 \%(\mathrm{v} / \mathrm{v})$ glycerol.

All strains were grown in brain-heart infusion (BHI; Oxoid) supplemented with $0.3 \%(\mathrm{w} / \mathrm{v})$ yeast extract (Difco) at $37^{\circ} \mathrm{C}$ for $18 \mathrm{~h}$ in an anaerobic jar. Cultures for biochemical characterization of strains were grown on Columbia-blood agar (Oxoid), with $5 \%$ (v/v) sheep's blood added, for $18 \mathrm{~h}$ at $37^{\circ} \mathrm{C}$ in an anaerobic atmosphere, unless otherwise stated.

Biochemical characterization and Lancefield grouping. The biochemical characterization of SMG strains followed the scheme of Whiley et al. (1990), with some modification. All streptococcal strains were tested for fermentation reactions in API 20Strep. test kits (API) and for the production of enzymes in API ZYM test kits and using substrates labelled with the fluorescent marker 4-methylumbelliferyl (Beighton \& Whiley, 1990). Production of hyaluronidase was determined by the rapid plate method of Smith \& Willet (1968). Lancefield grouping was performed on whole, washed cells from an overnight broth culture using the Streptex latex agglutination kit (Wellcome Diagnostics).

Binding of albumin to strains. All albumins, with the exception of rat albumin, were obtained from a commercial source (Sigma) and are shown in Fig. 1. Rat albumin was prepared by passing fresh rat plasma through a blue-Sepharose affinity column (Pharmacia LKB) and eluting with an $\mathrm{NaCl}$ gradient in PBS $\left(\mathrm{NaCl} 8 \mathrm{gl}^{-1}, \mathrm{KCl} 0.2 \mathrm{gl}^{-1}\right.$, $\mathrm{Na}_{2} \mathrm{HPO}_{4} 1 \cdot 15 \mathrm{~g} \mathrm{l}^{-1}, \mathrm{KH}_{2} \mathrm{PO}_{4} 0.2 \mathrm{~g} \mathrm{l}^{-1}$ ). The purity of all albumins was confirmed by polyacrylamide gel electrophoresis and showed a single band at $M_{\mathrm{r}} 63000$. Albumins were labelled with ${ }^{125} \mathrm{I}$ according to the method of Markwell (1982) and ${ }^{125} \mathrm{I}$-albumin was separated from unbound ${ }^{125}$ I by chromatography on PD-10 columns (Pharmacia LKB) containing $9 \cdot 1 \mathrm{ml}$ Sephadex G-25M, followed by dialysis against PBST [PBS containing Tween $20(0.5 \% \mathrm{v} / \mathrm{v})$ ].

The method of Willcox \& Knox (1990) was chosen to measure the binding of albumin to bacteria, with minor modifications. Cells from

Table 1. Characteristics of Streptococcus strains used

\begin{tabular}{|c|c|c|c|c|}
\hline $\begin{array}{c}\text { Strain } \\
\text { no. }\end{array}$ & Species & $\begin{array}{l}\text { Site of } \\
\text { isolation }\end{array}$ & $\begin{array}{l}\text { Lancefield } \\
\text { group }\end{array}$ & $\begin{array}{l}\text { Rat albumin } \\
\text { bound } \\
\text { (molecules } \\
\text { per cell) } \\
\pm \mathrm{SD} \dagger\end{array}$ \\
\hline POW1 & S. anginosus & $\begin{array}{l}\text { Appendiceal } \\
\text { abscess }\end{array}$ & $\mathrm{C}$ & $2768 \pm 176$ \\
\hline C117221-1 & S. anginosus & $\begin{array}{l}\text { Perirectal } \\
\text { abscess }\end{array}$ & $\mathrm{C}$ & $2553 \pm 172$ \\
\hline C5 & S. intermedius & Throat swab & $\mathrm{C}$ & $2828 \pm 137$ \\
\hline POW3 & S. intermedius & $\begin{array}{l}\text { Cerebral } \\
\text { abscess }\end{array}$ & $-*$ & $141 \pm 20$ \\
\hline POW5 & S. constellatus & Blood & F & $35 \pm 29$ \\
\hline F4 & S. anginosus & Sputum & F & $155 \pm 17$ \\
\hline G14 & S. anginosus & Sputum & G & $101 \pm 23$ \\
\hline G23 & S. constellatus & Sputum & $\mathbf{G}$ & $818 \pm 141$ \\
\hline G148 & $\begin{array}{l}\text { Large-colony } \\
\text { group G }\end{array}$ & Throat & $\mathrm{G}$ & $1919 \pm 70$ \\
\hline G43 & $\begin{array}{l}\text { Large-colony } \\
\text { group } \mathrm{G}\end{array}$ & Throat & $\mathrm{G}$ & $1764 \pm 138$ \\
\hline $\mathrm{C} 40$ & $\begin{array}{l}\text { Large-colony } \\
\text { group C }\end{array}$ & Throat & $\mathrm{C}$ & $1295 \pm 150$ \\
\hline
\end{tabular}

* The strain was non-groupable with Lancefield antisera.

$\dagger 1 \times 10^{-11} \mathrm{~mol}{ }^{125} \mathrm{I}$-labelled albumin added to $5 \times 10^{8}$ cells. 
broth cultures were washed and resuspended to an $\mathrm{OD}_{660}$ of 1.0 $\left(1 \times 10^{9}\right.$ cells ml $\left.{ }^{-1}\right)$ in PBST. The Tween 20 was added to reduce nonspecific binding to cells. Bacterial suspension $(0.5 \mathrm{ml})$ and $1 \times 10^{-11} \mathrm{~mol}$ albumin were allowed to interact for $30 \mathrm{~min}$ at ambient temperature $\left(22-26^{\circ} \mathrm{C}\right)$. Bacteria were separated from unbound ${ }^{125} \mathrm{I}$-albumin by centrifugation $(5000 \mathrm{~g}, 10 \mathrm{~min})$ and washed three times in PBST. The radioactivity associated with the bacterial pellet was then measured in a gamma counter. Control tubes containing no bacterial cells were also run and any radioactivity associated with these tubes was subtracted from the test tubes. The amount of binding was expressed as number of molecules per bacterial cell.

Initial experiments compared the ability of all bacteria to bind to rat albumin. Subsequently, strain C5 was tested for its ability to bind to other albumin types. Finally, other group C SMG, strains F4, G14 and G23 and large-colony group C and G strains were compared for their ability to bind to rat, human, rabbit and cow albumins in order to assess the conservation of the specific binding.

Localization of albumin receptor. Human albumin was coupled with colloidal gold by an established technique (Beesley, 1989) and allowed to interact with bacteria (strains C5, C117221-1, POW1 or F4) on a carbon-Formvar grid as described previously (Wyatt et al., 1988) using PBST as the buffer. After negative staining with methylamine tungstate, the grids were examined by transmission electron microscopy.

Factors affecting albumin binding. Strain C5 was used exclusively for further study into the molecular nature of the receptor for albumin. To test for any effect of subculturing, cells were grown on Columbia-blood agar, passaged into BHI and then sequentially passaged on agar and into broth until the culture had been grown in broth 30 times. The cells were then assayed for their ability to bind to rat albumin. In other experiments, cells $\left(1 \times 10^{9} \mathrm{ml}^{-1}\right)$ were treated with either proteinase $\mathrm{K}$ (Sigma), lipase (Sigma) or periodate. For periodate treatment, cells were resuspended in $0.1 \mathrm{M}$-sodium phosphate buffer ( $\mathrm{pH} 6.5$ ) containing 20 mM-periodic acid, incubated for $20 \mathrm{~min}$ at $4{ }^{\circ} \mathrm{C}$ and washed in $\mathrm{NaBH}_{4}$ (Sandgren et al., 1991). After treatment, the cells were resuspended to an $\mathrm{OD}_{660}$ of 1.0 in PBST and allowed to interact with rat ${ }^{125} \mathrm{I}$-albumin in solution.

The ability of substances to interfere with binding was measured by incubating cells in $1 \mathrm{mg} \mathrm{ml}^{-1}$ of either non-immune $\mathrm{IgG}$, rabbit IgG to $S$. mutans protein P1 (Forester et al., 1983), serum to group C polysaccharide (Difco), or rabbit IgG to lipoteichoic acid (Wicken \& Knox, 1971), or in an equal concentration $\left(1 \times 10^{-11} \mathrm{~mol}\right)$ of human albumin, bovine albumin or ovalbumin (Sigma). The ability to affect the number of rat ${ }^{125} \mathrm{I}$-albumin molecules was assessed either after treatment (IgG) or by adding the rat albumin together with the other albumins. Statistical analysis, using Spearman's rank test, was performed to demonstrate which treatments had an effect.

Extraction of receptor. Approximately $9 \mathrm{~g}$ wet weight of cells (from a 6-litre culture of strain $\mathrm{C5}$ ) was divided equally for extractions by the nine procedures described below.

Cells were boiled for $10 \mathrm{~min}$ in either PBS (neutral extraction), in PBS adjusted to $\mathrm{pH} 2$ (with $\mathrm{HCl}$ ) or adjusted to $\mathrm{pH} 10$ (with $\mathrm{NaOH}$ ), or in PBS containing $0.5 \%$ sodium dodecyl sulphate (SDS extraction). The cells were then separated by centrifugation and the supernatants adjusted to $\mathrm{pH} 7 \cdot 0$. These methods are modifications of methods used previously to extract albumin receptors from 'large-colony' ( $S$. dysgalactiae) group C streptococci (Raeder et al., 1991).

For enzymic liberation of receptor, cells were incubated at $37^{\circ} \mathrm{C}$ for $18 \mathrm{~h}$ with either 0.2 units insoluble trypsin (Sigma; Lämmler et al., 1987), $5 \mathrm{mg}$ lysozyme (Sigma; Lämmler \& Sting, 1989), $10 \mathrm{mg}$ mutanolysin (Sigma) in $10 \mathrm{ml}$ PBS or $10 \mathrm{mg}$ mutanolysin in $10 \mathrm{ml} 0.02 \mathrm{M}$-Tris/ $\mathrm{HCl}$ buffer $\left(\mathrm{pH} 7.0\right.$ ) containing $0.01 \mathrm{M}-\mathrm{MgSO}_{4}$ and $40 \%(\mathrm{w} / \mathrm{v})$ raffinose (this solution prevents cell lysis; data not presented). Cells were removed by centrifugation and filtration through
$0.22 \mu \mathrm{m}$ filters. Cell-surface proteins were also extracted with $1 \%(\mathrm{w} / \mathrm{v})$ sodium lauroylsarcosinate (SLS) for $20 \mathrm{~min}$ at ambient temperature followed by centrifugation (Jenkinson, 1986). All extracts were stored at $-20^{\circ} \mathrm{C}$ until required.

To assess the extraction of a functional receptor and its molecular mass, molecules were separated by SDS-PAGE on 4-15\% gels using a Phast system (Pharmacia LKB). Gels were either stained with Coomassie blue or subjected to Western blotting in a semi-dry transfer apparatus attached to the Phast system. After transfer to nitrocellulose membranes, the membranes were washed three times in PBST [containing $5 \%(\mathrm{w} / \mathrm{v})$ skim milk powder] and then incubated with $200 \mu \mathrm{g}{ }^{125} \mathrm{I}$-human albumin in PBST + milk for $1 \mathrm{~h}$. After three washes in PBST, autoradiography was performed at $-20^{\circ} \mathrm{C}$ for $48 \mathrm{~h}$.

Purification of receptor. An affinity column of human albumin Sepharose was prepared by treating CNBr-labelled Sepharose (Pharmacia LKB) with human albumin according to the manufacturer's instructions. The active extract (containing a functional receptor), in $50 \mathrm{mM}-\mathrm{Tris} / \mathrm{HCl}(\mathrm{pH} \mathrm{7.5)}$, was applied to the column and washed sequentially with $1 \mathrm{M}-\mathrm{NaCl}, 1 \mathrm{M}$-urea, $4 \mathrm{M}$-urea and $0.2 \mathrm{M}$ glycine/ $\mathrm{HCl}$ buffer ( $\mathrm{pH} 2 \cdot 6$ ). Fractions were then subjected to SDSPAGE and autoradiography (as described above) to identify those containing the receptor.

Characterization of purified receptor. The purified receptor $(20 \mu \mathrm{g})$ was allowed to interact with $1 \times 10^{-11} \mathrm{~mol}{ }^{125} \mathrm{I}$-human albumin in solution for $30 \mathrm{~min}$ at ambient temperature before adding $5 \times 10^{8}$ cells of C5 in PBST for $30 \mathrm{~min}$ at ambient temperature. The cells were separated from solution by centrifugation $(5000 \mathrm{~g}, 10 \mathrm{~min})$ and washed three times in PBST. The purified receptor was also incubated with $20 \mathrm{mg}$ (protein) insoluble trypsin (Sigma) for $1 \mathrm{~h} \mathrm{at} 37^{\circ} \mathrm{C}$. After incubation, the insoluble trypsin was removed by centrifugation $(5000 \mathrm{~g}, 10 \mathrm{~min})$ and the supernatant fraction tested for its ability to interfere with albumin binding to whole cells. To test for the ability of the purified receptor to bind IgG, the purified receptor was subjected to SDS-PAGE, Western blotted onto nitrocellulose and then incubated for $1 \mathrm{~h}$ in PBST + milk (see above) containing ${ }^{125} \mathrm{I}$-human IgG. Excess IgG was removed by washing in PBST + milk and the nitrocellulose was then subjected to autoradiography.

Dot-blot Southern hybridization. Chromosomal DNA was isolated from all the strains. After growth in BHI for $18 \mathrm{~h}$ at $37^{\circ} \mathrm{C}$, the cells were centrifuged, resuspended in $20 \mathrm{ml}$ fresh BHI and incubated for $2 \mathrm{~h}$ at $37^{\circ} \mathrm{C}$. The cells were then washed once in TE buffer $(50 \mathrm{~mm}$ Tris/ $\mathrm{HCl} \mathrm{pH} \mathrm{7.5;} 20$ mM-EDTA), mutanolysin (125 units) was added and the cells were incubated at $60^{\circ} \mathrm{C}$ until a marked decrease in opalescence of the suspension was observed (usually between 1 and $2 \mathrm{~h}$ ). After lysing cells by the addition of $20 \mu \mathrm{l} 20 \%$ (w/v) SDS, $0.06 \mathrm{mg}$ proteinase $\mathrm{K}$ was added and incubated at $37^{\circ} \mathrm{C}$ for $1 \mathrm{~h}$. Protein was then precipitated by the addition of $200 \mu$ l saturated $\mathrm{NaCl}$ solution and removed by centrifugation $(7000 \mathrm{~g}, 10 \mathrm{~min})$. DNA was then precipitated with 0.6 vols 2-propanol. After centrifugation and drying the pellet, the DNA was resuspended in TE, incubated with RNAase (final concn $10 \mathrm{mg} \mathrm{ml}^{-1}$ ) to remove residual RNA and extracted with an equal volume of phenol, followed by phenol/chloroform and finally chloroform (Sambrook et al., 1989).

An oligonucleotide probe (AAATATGGAGTAAGTGACTAT) that corresponded to a conserved portion of protein $G$ gene that encodes for the albumin-binding region (Otten \& Boyle, 1991) was synthesized using a Gene Assemble Plus synthesizer (Pharmacia LKB). The probe was then labelled with ${ }^{32} \mathrm{P}$ using a commercially available kit (Amersham).

Chromosomal DNA was made single-stranded by boiling and then $20 \mathrm{ng}$ dotted onto a nylon membrane (Hybond $\mathrm{N}+$; Amersham). Using commercially available buffers and blocking agents (Amersham) the membrane was probed with $10 \mathrm{ng}$ of the oligonucleotide probe at 
$42^{\circ} \mathrm{C}$. After washing with $0.5 \times$ or $0.1 \times \mathrm{SSC}(0.5 \times \mathrm{SSC}$ is sodium citrate, $7.5 \mathrm{~mm}$; sodium chloride, $75 \mathrm{mM}$ ), hybridization was measured by exposing the membrane to photographic film (Hyperfilm-MP; Amersham).

Ability of strains to hydrolyse albumin. This was measured in two ways. Bacteria were grown on Columbia-blood agar, and the growth was harvested and suspended in $50 \mathrm{~mm}$-Tris $/ \mathrm{HCl}$ buffer $(\mathrm{pH} 7.5)$ to an $\mathrm{OD}_{620}$ of $0.1\left(1 \times 10^{8} \mathrm{cells} \mathrm{mi}^{-1}\right)$. The bacterial suspension $(50 \mu \mathrm{l})$ was mixed with $50 \mu \mathrm{l}$ fluorescein-isothiocyanate-labelled bovine serum albumin (Sigma) and incubated for $24 \mathrm{~h}$ at $37^{\circ} \mathrm{C}$. After incubation the mixture was examined for an increase in fluorescence under UV light.

A second method was developed which allowed the hydrolysis of human serum albumin to be examined. Strains were grown in BHI and resuspended in PBS to an $\mathrm{OD}_{660}$ of 1.0. The method then followed that for measuring binding to albumin (see above). After incubation of strains with ${ }^{125} \mathrm{I}$-labelled albumin, the unbound albumin was removed by centrifugation and washing in PBS and the cells then boiled in $0.5 \%$ SDS to remove the bound albumin. The SDS-soluble material was then subjected to SDS-PAGE on $8-25 \%$ gradient gels, Westernblotted onto nitrocellulose and a film (Hyperfilm-MP; Amersham) was exposed to the blot. Controls of albumin alone were also run. The number of radiolabelled band(s) demonstrated the integrity or otherwise of the albumin.

\section{Results}

\section{Biochemical characterization of strains}

The species to which the various SMG strains belonged are listed in Table 1. Representatives of all three species within the SMG were identified and conformed to the published reactions (Beighton \& Whiley, 1990; Whiley et $a l ., 1990)$. Three strains reacted with Lancefield group $\mathrm{C}$ antisera, two with Lancefield group $\mathrm{G}$ antisera, two were Lancefield group $F$ positive and one was ungroupable.

\section{Binding of albumin to strains}

Table 1 demonstrates that Lancefield group $\mathrm{C}$ strains bound considerably more $(>16 \times)$ rat albumin than the other strains. The amount bound was not related to species or site of isolation. The ability to bind albumin was found to be a stable characteristic as repeated subculture $(30 \times)$ of strain $\mathrm{C} 5$ did not reduce the amount of albumin bound.

$S$. intermedius strain C5 was selected for further study into the types of albumins bound by the group $\mathrm{C}$ strains of SMG. As can be seen in Fig. 1, C5 bound considerably more human, monkey, baboon, dog, cat, mouse, hamster and guinea-pig albumin than horse, rabbit, pig, sheep, cow, goat or chicken albumin, with rat and donkey albumin giving intermediate values. To determine whether this specificity was possibly a general feature of group C SMG, the binding of rat, human, rabbit and cow albumins was measured; all the group $C$ strains gave similar results (Table 2). Table 2 also demonstrates that S. anginosus F4 (group F) and G14 (group G) did not bind large amounts of any of the albumins tested, whereas the large-colony group $\mathrm{C}$ and $\mathrm{G}$ streptococci all bound albumins in the order human $>$ rat $>$ cow $>$ rabbit, and, in general, strain G148 bound more albumin than the others.

\section{Localization of albumin receptor}

The albumin-gold conjugate was located very near the cell surface for all three Lancefield group C SMG (Fig. 2). The control, albumin-gold interaction with $S$.

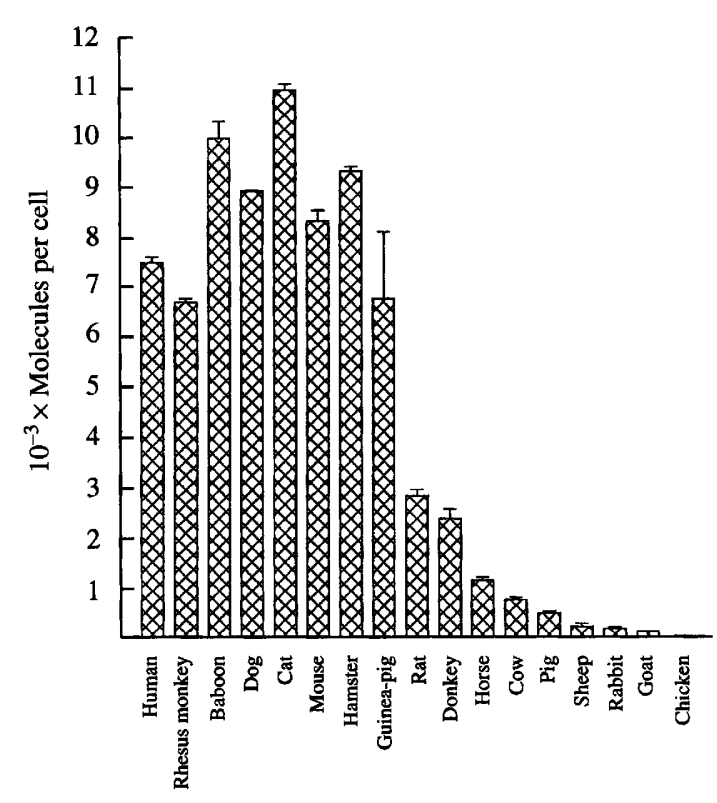

Albumin type

Fig. 1. Binding of albumin to S. intermedius C5 Lancefield group C. The bars represent standard deviation about the mean.

Table 2. Ability of streptococcal strains to bind to different albumin types

\begin{tabular}{lcccc}
\hline \hline & \multicolumn{4}{c}{ Albumin bound (molecules per cell) \pm sD $\dagger$} \\
\cline { 2 - 5 } \multicolumn{1}{c}{ Strain* } & Rat & Human & Rabbit & Cow \\
\hline POW1 (C) & $2768 \pm 176$ & $8232 \pm 70$ & $37 \pm 7$ & $244 \pm 38$ \\
C117221-1 (C) & $2553 \pm 172$ & $7092 \pm 34$ & $14 \pm 4$ & $131 \pm 44$ \\
C5 (C) & $2828 \pm 137$ & $7488 \pm 116$ & $75 \pm 5$ & $180 \pm 31$ \\
F4 (F) & $155 \pm 17$ & $28 \pm 4$ & $11 \pm 3$ & $13 \pm 4$ \\
G14 (G) & $101 \pm 23$ & $8 \pm 3$ & $-1 \cdot 7 \pm 7$ & $4 \pm 3$ \\
G23 (G) & $818 \pm 141$ & $204 \pm 59$ & $13 \pm 4$ & $22 \pm 8$ \\
G148 (G) $\ddagger$ & $1919 \pm 70$ & $8173 \pm 307$ & $83 \pm 25$ & $112 \pm 88$ \\
G43 (G) $\ddagger$ & $1764 \pm 138$ & $4392 \pm 448$ & $14 \pm 6$ & $116 \pm 15$ \\
C49 (C) $\ddagger$ & $1295 \pm 150$ & $5532 \pm 559$ & $62 \pm 6$ & $117 \pm 63$ \\
\hline \hline
\end{tabular}

* Serological group in parentheses.

$\dagger 1 \times 10^{-11}$ mol ${ }^{125} \mathrm{I}$-labelled albumin added to $5 \times 10^{8}$ cells. $\ddagger$ Large-colony streptococci, not SMG. 

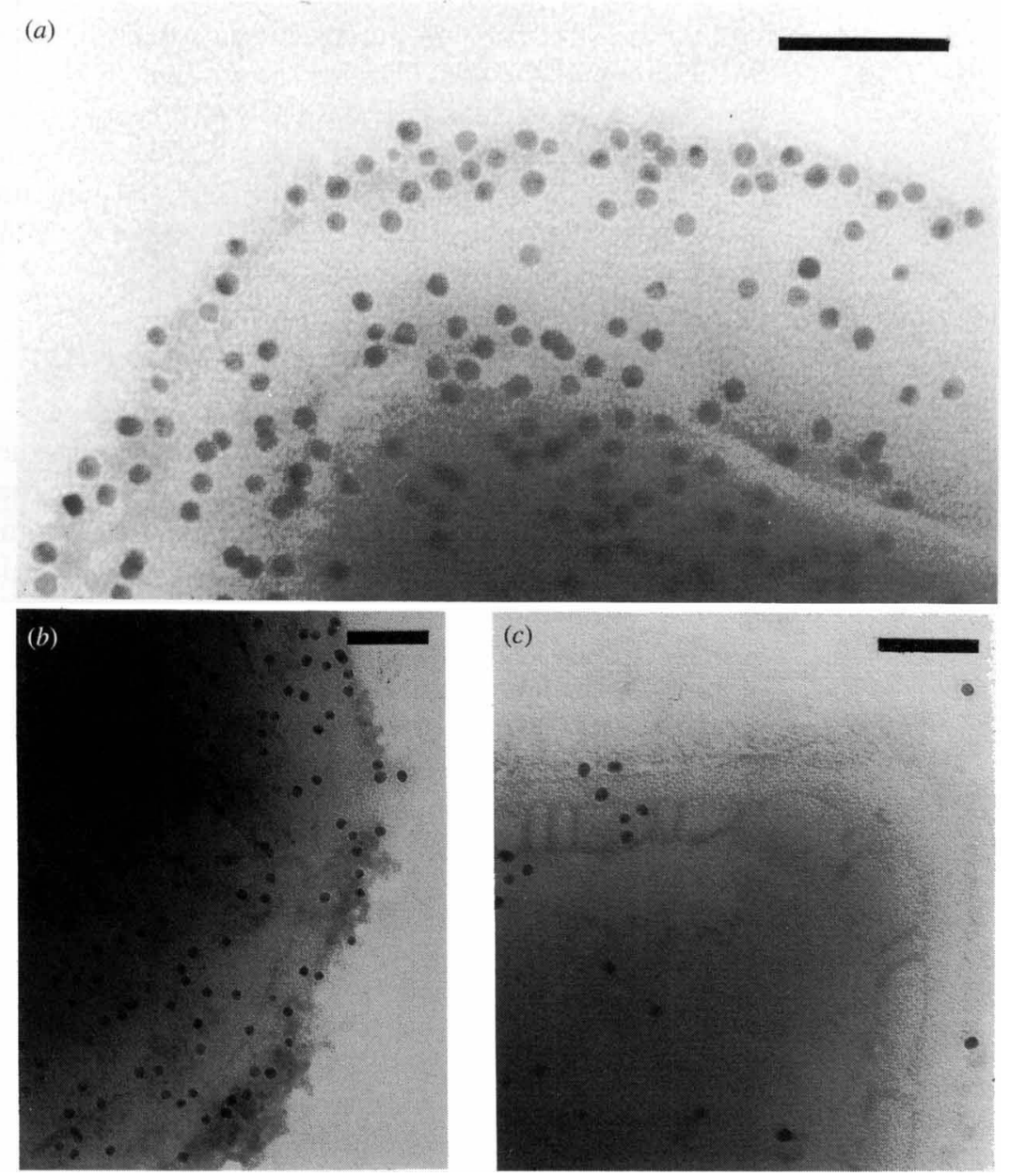

Fig. 2. Electron micrographs of albumin-colloidal-gold-labelled Lancefield group C $S$. milleri strains. (a) Strain C5; (b) strain C117221-1; (c) strain POW1. The gold particles are close to the surface of the cells. Bars, $50 \mathrm{~nm}$.

Table 3. Effect of various treatments on the ability of strain $C 5$ to bind albumin

The values are the means of six replicates. Standard deviations were always less than $20 \%$ of the mean values.

\begin{tabular}{lc}
\hline \multicolumn{1}{c}{ Treatment } & $\begin{array}{c}\text { Rat albumin bound } \\
\text { (mols per cell) }\end{array}$ \\
\hline None & 2828 \\
Proteinase K & $368^{*}$ \\
Lipase & 2687 \\
Periodate & 2319 \\
IgG (non-immune) & 2545 \\
IgG to P1 & 3422 \\
IgG to LTA & 3394 \\
IgG to group C polysaccharide & 2970 \\
Human albumin & $961^{*}$ \\
Bovine albumin & $1607^{*}$ \\
Ovalbumin & 2513 \\
\hline \hline
\end{tabular}

* Significant $(P<0.01)$ effect of the treatment on the ability of cells to bind albumin.

anginosus $\mathrm{F} 4$, did not show any gold particles on grids (data not shown). The photomicrograph of POW1 (Fig. $2 c$ ) shows a protuberance or tuft on the cell surface. It can be seen that only one albumin-gold conjugate adhered to this part of the cell, whereas far more albumin-gold adhered to the rest of the cell surface.

\section{Factors affecting albumin binding}

The effects of various procedures on the cell surface of strain C5 were examined with a view to determining the molecular identity of the albumin receptor (Table 3). Proteinase $\mathrm{K}$ reduced the binding to rat albumin, whereas lipase and periodate treatment of cells did not reduce binding, indicating that binding does not involve lipid or carbohydrate. IgG to group C polysaccharide, S. mutans protein P1, LTA, or non-immune IgG similarly had no effect. Human and, to a lesser extent, cow albumins were able to compete with the labelled rat albumin for the receptor, whereas ovalbumin was ineffective.

\section{Extraction of receptor}

Of the various methods that were tested for their ability to extract a functional receptor, only incubation for $18 \mathrm{~h}$ with lysozyme was effective. After SDS-PAGE, Western blotting and autoradiography, the $M_{\mathrm{r}}$ of the receptor was estimated to be 24000 . Only one band was seen after 


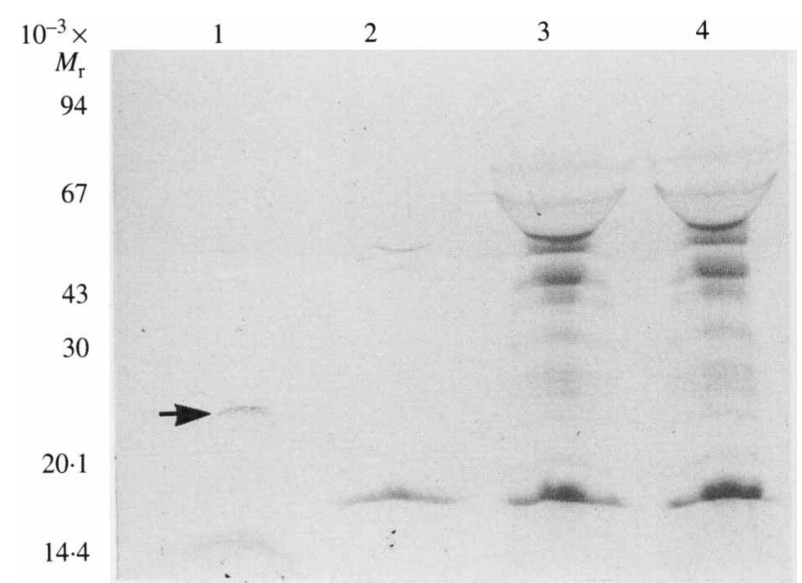

Fig. 3. SDS-PAGE of lysozyme-extracted proteins from strain C5 after affinity chromatography on human albumin-Sepharose. Lanes: 1, fraction eluted with $0.2 \mathrm{M}$-glycine/ $\mathrm{HCl}, \mathrm{pH} 2 \cdot 6 ; 2$, fraction eluted with $1 \mathrm{M}-\mathrm{NaCl} ; 3$, void volume; 4, lysozyme-treated C5 prior to affinity chromatography. The positions of molecular mass markers are indicated on the left. The arrow indicates the position of the receptor for ${ }^{125}$ I-labelled albumin, approximate $M_{\mathrm{r}} 24000$.

autoradiography, indicating that the strains possessed only one receptor type for albumin.

\section{Purification of receptor}

Fig. 3 shows the SDS-PAGE profiles of the peaks obtained after affinity chromatography and the position of the band visible on autoradiographs. A number of proteins eluted in the void volume; $1 \mathrm{M}-\mathrm{NaCl}$ eluted a major component of $M_{\mathrm{r}} 18000$; elution with $1 \mathrm{M}$ - or $4 \mathrm{M}$ urea did not elute any component. Glycine/ $\mathrm{HCl}$ buffer (pH 2.6) eluted several components with two major bands of $M_{\mathrm{r}} 24000$ and 14000 . The autoradiograph demonstrated that the albumin receptor was eluted with glycine $/ \mathrm{HCl}$ and was localized to the 24000 protein band.

\section{Characterization of purified receptor}

A comparison of radioactivity associated with the cells with and without added receptor showed that a $75 \%$ reduction in albumin binding had occurred in the presence of the receptor. Incubation of the receptor with insoluble trypsin at $37^{\circ} \mathrm{C}$ destroyed its ability to inhibit albumin binding, which is consistent with it being a protein. The purified receptor failed to bind ${ }^{125} \mathrm{I}-\mathrm{IgG}$ as shown by the lack of reactive bands after autoradiography.

\section{Test for similarity to protein $G$}

The possible relation between the albumin receptors of SMG and protein G of large-colony group G Streptococcus was investigated. An oligonucleotide probe was synthesized and used to probe chromosomal DNA of SMG. None of the SMG strains showed reactivity with the probe in conditions of high or low stringency, which may indicate that they do not possess the identical gene for the protein $G$ albumin-binding region (data not presented). The only strain that did hybridize with the probe was large-colony group G strain G148.

\section{Hydrolysis of albumin}

Two methods were developed to determine whether SMG strains were able to hydrolyse albumin, as enzymes may function as receptors. In neither case could any evidence of hydrolysis be detected. No SMG strain showed an increase in fluorescence after incubation of cells for $18 \mathrm{~h}$ at $37^{\circ} \mathrm{C}$ with fluorescein-labelled albumin. Similarly, when the Lancefield group C SMG strains were incubated with ${ }^{125} \mathrm{I}$-human albumin for $30 \mathrm{~min}$ and the albumin removed from the cell surface by boiling in detergent, no evidence of albumin degradation could be shown after SDS-PAGE and autoradiography of the extract.

\section{Discussion}

This study has demonstrated that SMG strains that react with Lancefield group $\mathrm{C}$ antisera are able to bind large amounts of certain types of albumin to their cell surface. No other SMG strain was able to do this to any great extent and the reaction was independent of the species within the SMG. It has been reported that Lancefield group C strains account for approximately $9 \%$ of all SMG isolates (Gossling, 1988; Whiley et al., 1990). This may be an underestimate as a common practice in routine bacteriology laboratories is to differentiate $\beta$ haemolytic streptococci solely on their possession of Lancefield group antigens and therefore group C SMG would be reported simply as group $\mathrm{C}$ streptococci. Indeed, $56-75 \%$ of all group C streptococci isolated from infections are SMG (Lawrence et al., 1985; Lebrun et al., 1986; Ruoff et al., 1985). While there has been only one report on the binding of albumin (cow) by SMG (Willcox et al., 1992), the ability of other streptococci carrying Lancefield group $\mathrm{C}$ and $\mathrm{G}$ antigens, namely $S$. dysgalactiae, $S$. canis, $S$. zooepidemicus, $S$. equi and $S$. equisimilis, to bind albumin has been studied in some detail (Sjöbring et al., 1991; Wideback \& Kronvall, 1982; Raeder et al., 1991; Lämmler et al., 1988; Otten \& Boyle, 1991); five or more different types of albumin receptor have been described which are differentiated by their ability to bind specific albumin types. The albumin receptor on SMG strains may be related to 'type a' receptor found on $S$. equisimilis and human group $\mathrm{G}$ 
streptococci as both types bind human, mouse and dog albumin but not rabbit or cow albumin.

The ability of SMG strains to bind different albumins is probably the property of a single cell-surface component, as human albumin and, to a lesser extent, cow albumin could inhibit the binding of rat albumin to the bacteria. The inhibition seen with cow albumin indicates that the low level of binding was of a specific nature. The receptor for albumin was shown to be a protein. It could be removed from the cell surface by proteinase digestion of whole cells, stained with Coomassie blue after purification on albumin-Sepharose, and the purified receptor lost its ability to inhibit the binding of labelled albumin to the surface of the SMG after digestion with proteinase K. Albumin-gold labelling of the surface of the streptococci revealed that the albumin receptor was situated very close to the cell wall. Tufts and fimbriae have been demonstrated on the surface of SMG (Willcox \& Drucker, 1989; unpublished data), but it appears unlikely that the receptor is associated with these structures.

SDS-PAGE of the purified receptor and of lysozymeextracted receptor revealed that its $M_{\mathrm{r}}$ was 24000 . This value was less than the $M_{\mathrm{r}}$ values of albumin receptors extracted from large-colony group C or G streptococci, which range from 48000-51000 (Sjöbring, 1992; Lämmler et al., 1988). The oligonucleotide probe synthesized to match a conserved region of the albuminbinding domain to protein $\mathrm{G}$, an albumin 'type a' and IgG binding molecule of large-colony group $\mathrm{C}$ and $\mathrm{G}$ streptococci, showed no homology to total DNA of SMG; this is consistent with previous reports that SMG cannot bind to IgG (Lebrun et al., 1986) and may indicate that the SMG receptor is not protein $G$ but a unique albumin-binding molecule. The $\mathrm{G}+\mathrm{C}$ ratio of SMG is $37-42 \mathrm{~mol} \%$ (Drucker \& Lee, 1983; Ezaki et al., $1986)$ and of large-colony group C (S. equi, S. zooepidemicus, $S$. dysgalactiae and $S$. equisimilis) and largecolony group G streptococci is $37-40 \mathrm{~mol} \%$ (Ezaki et al., 1986). These similar values may indicate that the non-homology with the oligonucleotide is not the result of different codon usage between the groups. Albumin receptors, and many IgG receptors, can be removed from streptococci by boiling at acidic $\mathrm{pH}$ (Raeder et al., 1991; Lämmler et al., 1988). In contrast, the albumin receptor of strain $\mathrm{C} 5$ was either not released by boiling at acidic $\mathrm{pH}$ or was destroyed as no reactive bands could be seen after SDS-PAGE and autoradiography. This finding also points to differences between the receptor on the SMG and other streptococcal albumin receptors. Glycine $/ \mathrm{HCl}$ buffer eluted more than one band from the affinity column, which may be the result of degradation of the receptor by the low $\mathrm{pH}$ of the buffer, and this may parallel the inability of acid to liberate a functional receptor from the surface of cells. Indeed, an overloaded SDS-PAGE gel of the purified receptor showed considerable 'laddering', with bands being detected between $M_{\mathrm{r}} 24000$ and 14000 (data not shown).

It has been previously demonstrated that lipoteichoic acid (LTA) can bind to albumin via its lipid component (Simpson et al., 1980). The demonstration that lipase digestion of the cell surface did not reduce albumin binding indicates that lipids were not involved in the binding. The addition of Tween 20 to the buffer system which can elute LTA from albumin (Simpson et al., 1980), and the fact that group F SMG possess LTA-like material (Whitworth et al., 1992) but did not bind large amounts of albumin, makes it unlikely that LTA contributes to albumin binding. Enzymes can act as receptors and a report has demonstrated that SMG strains can degrade bovine albumin (Homer et al., 1990). Under the growth conditions employed in this study no SMG strain was able to degrade bovine or human albumin, and it seems unlikely therefore that the protein responsible for albumin binding also has enzymic ability.

In conclusion, the data presented in this study indicate that certain SMG strains are able to bind to albumin and that the cell-surface receptor for albumin of a strain of $S$. intermedius has an $M_{\mathrm{r}}$ of 24000 . Further work is currently in progress to isolate the gene encoding the receptor for albumin and to make mutants of SMG strains that lack albumin-binding ability, to assess the possible role of binding as a pathogenic determinant.

This research was supported by grants from the NHMRC, the Dental Board of New South Wales and the Australian Dental Research Fund Inc.

\section{References}

Beighton, D. \& Whiley, R. A. (1990). Sialidase activity of the 'Streptococcus milleri group' and other viridans streptococci. Journal of Clinical Microbiology 28, 1431-1433.

BeEsLey, J. E. (1989). Colloidal Gold: a New Perspective for Cytochemical Marking, p. 10. Oxford: Oxford University Press.

Cimolai, N., Elford, R. W., Bryan, L., Anand, C. \& Berger, P. (1988). Do the $\beta$-hemolytic non-group A streptococci cause pharyngitis? Reviews of Infectious Diseases 10, 587-601.

DRUCKER, D. B. \& GREEN, R. M. (1978). The relative cariogenicities of Streptococcus milleri and other viridans group streptococci in gnotobiotic hooded rats. Archives of Oral Biology 23, 183-187.

Drucker, D. B. \& LeE, S. M. (1983). Possible heterogeneity of Streptococcus milleri determined by DNA mol \% (guanine plus cytosine) measurement and physiological characterization. Microbios 38, 151-157.

Ericson, D., Buörck, L. \& Kronvall, G. (1980). Further characteristics of $\beta_{2}$-microglobulin binding to oral streptococci. Infection and Immunity 30, 117-124.

Ezaki, T., Facklam, R., Takeuchi, N. \& YabuUChI, E. (1986). Genetic relatedness between the type strain of Streptococcus anginosus and minute-colony-forming beta-hemolytic streptococci carrying different Lancefield grouping antigens. International Journal of Systematic Bacteriology 36, 345-347.

Finlay-Jones, J. J., Hart, P. H., Spencer, L. K., Nulsen, M. F., KENNY, P. A. \& MCDONALD, P. J. (1991). Bacterial killing in vitro by 
abscess-derived neutrophils. Journal of Medical Microbiology 34, $73-81$.

FORESTER, H., HuNTER, N. \& KNOX, K. W. (1983). Characteristics of a high molecular mass extracellular protein of Streptococcus mutans. Journal of General Microbiology 129, 2779-2788.

GossLing, J. (1988). Occurrence and pathogenicity of the Streptococcus milleri group. Reviews of Infectious Diseases 10, 257-285.

Homer, K. A., Whiley, R. A. \& Beighton, D. (1990). Proteolytic activity of oral streptococci. FEMS Microbiology Letters 67, 257-260.

JENKINSON, H. F. (1986). Cell-surface proteins of Streptococcus sanguis associated with cell hydrophobicity and coaggregation properties. Journal of General Microbiology 132, 1575-1589.

LäMmLER, C. \& STING, R. (1989). Interaction of type II IgG Fcreceptors from streptococci of serological group A with murine IgG. Zentralblatt für Bakteriologie 271, 460-465.

LÄmmler, C., Schaufuss, P., Frede, C. \& Blobel, H. (1987). Binding of plasma proteins to streptococci of serological group $\mathrm{L}$ with special reference to their immunoglobulin G Fc-receptor activity. Canadian Journal of Microbiology 34, 1-5.

Lämmler, C., Frede, C., Gurturk, K., Hildebrand, A. \& Blobel, H. (1988). Binding activity of Streptococcus canis for albumin and other plasma proteins. Journal of General Microbiology 134, 2317-2323.

LAWRENCE, J., YAJKo, D. M. \& HADLEY, W. K. (1985). Incidence and characterisation of beta-hemolytic Streptococcus milleri and differentiation from $S$. pyogenes (group A), S. equisimilis (group C), and large-colony group $\mathrm{G}$ streptococci. Journal of Clinical Microbiology 22, 772-777.

Lebrun, L., Guibert, M., Wallet, P., De Maneville, M.-M. \& PILLOT, J. (1986). Human $\mathrm{Fc}(\gamma)$ receptors for differentiation in throat cultures of group C 'Streptococcus equisimilis' and group C 'Streptococcus milleri'. Journal of Clinical Microbiology 24, 705-707.

MARKWELL, M. A. K. (1982). A new solid-state reagent to iodinate proteins. Analytical Biochemistry 125, 427-432.

MEJÀRÉ, B. \& EdWARDSSON, S. (1975). Streptococcus milleri (Guthof); an indigenous organism of the human oral cavity. Archives of Oral Biology 20, 757-762.

Miörner, H., MyHre, E., BJörCK, L. \& Kronvall, G. (1980). Effect of specific binding of human albumin, fibrinogen, and immunoglobulin $\mathbf{G}$ on surface characteristics of bacterial strains as revealed by partition experiments in polymer phase systems. Infection and Immunity 29, 879-885.

Moore-Gillon, J. C., EYKYN, S. J. \& Phillips, I. (1981). Microbiology of pyogenic liver abscess. British Medical Journal 283, 819-821.

OTtEN, R. A. \& BoYle, M. D. P. (1991). Characterisation of protein G expressed by human group $\mathrm{C}$ and $\mathrm{G}$ streptococci. Journal of Microbiological Methods 13, 185-200.

RaEDER, R., OtTEN, R. A. \& Boyle, M. D. P. (1991). Comparison of albumin receptors expressed on bovine and human group $\mathbf{G}$ streptococci. Infection and Immunity 59, 609-616.

RuOFF, K. L. (1988). Streptococcus anginosus ('Streptococcus milleri'): the unrecognised pathogen. Clinical Microbiology Reviews 1, $102-108$.

Ruoff, K. L., Kunz, L. J. \& Ferraro, M. J. (1985). Occurrence of Streptococcus milleri among beta-hemolytic streptococci isolated from clinical specimens. Journal of Clinical Microbiology 22, 149-151.

Sambrook, J., Fritsch, E. F. \& Maniatis, T. (1989). Molecular Cloning, A Laboratory Manual, 2nd edn. Cold Spring Harbor, NY: Cold Spring Harbor Laboratory.

SANDGRen, C. H., Mamo, W., LaRsson, I., Lindahl, M. \& BJörK, I. (1991). A periodate-sensitive anti-phagocytic surface structure, induced by growth in milk whey, on Staphylococcus aureus isolated from bovine mastitis. Microbial Pathogenesis 11, 211-220.
Simpson, W. A., OfeK, I. \& Beachey, E. H. (1980). Binding of streptococcal lipoteichoic acid to the fatty acid binding sites on serum albumin. Journal of Biological Chemistry 255, 6092-6097.

SJöBRING, U. (1992). Isolation and molecular characterisation of a novel albumin-binding protein from group $\mathrm{G}$ streptococci. Infection and Immunity 60, 3601-3608.

SJÖBRING, U., BJöRCK, L. \& KASTERN, W. (1991). Streptococcal protein G: gene structure and protein binding properties. Journal of Biological Chemistry 266, 399-405.

SMITH, R. F. \& WILLET, N. P. (1968). Rapid plate method for screening hyaluronidase and chondroitin sulfatase-producing microorganisms. Applied Microbiology 16, 1434-1436.

Switalski, L. M., MurChison, H., Timpl, R., CuRTiss III, R. \& HoOK, M. (1987). Binding of laminin to oral and endocarditis strains of viridans streptococci. Journal of Bacteriology 169, 1095-1101.

UllberG, M., Kronvall, G. \& Wiman, B. (1989). New receptor for human plasminogen on gram positive cocci. APMIS 97, 996-1002.

WAGNeR, B., SCHMIDT, K.-H., WAGNER, M. \& KöHLER, W. (1986). Albumin bound to the surface of M-protein positive streptococci increased their phagocytosis by polymorphonuclear leukocytes in the absence of complement and bactericidal antibodies. Zentralblatt für Bakteriologie, Mikrobiologie und Hygiene, Series A 261, 432-446.

WHILEY, R. A. \& HARDIE, J. M. (1989). DNA-DNA hybridization studies and phenotypic characteristics of strains within the 'Streptococcus milleri' group. Journal of General Microbiology 135, 2623-2633.

Whiley, R. A., Fraser, H., Hardie, J. M. \& Beighton, D. (1990). Phenotypic differentiation of Streptococcus intermedius, Streptococcus constellatus, and Streptococcus anginosus strains within the 'Streptococcus milleri group'. Journal of Clinical Microbiology 28, 1497-1501.

Whitworth, J. M., Poxton, I. R. \& Ross, P. W. (1992). Immunochemistry of the membrane associated carbohydrate antigens of group $\mathrm{F}$ and related streptococci $(S$. milleri). In New Perspectives on Streptococci and Streptococcal Infections (Zentralblatt für Bakteriologie suppl. 22), pp. 219-220. Edited by G. Orefici. Stuttgart: Gustav Fischer Verlag.

WICKEN, A. J. \& KNOX, K. W. (1971). A serological comparison of the membrane teichoic acids from lactobacilli of different serological groups. Journal of General Microbiology 67, 251-254.

WidebaCK, K. \& KRONVAll, G. (1982). Surface receptors for serum albumin in group $\mathrm{C}$ and $\mathrm{G}$ streptococci show three different types of albumin specificity. Infection and Immunity 38, 1154-1163.

Wideback, K., SEAL, U. S. \& KronVAlL, G. (1982). Receptor in group C and G streptococci detects albumin structures present in mammalian species. Infection and Immunity 36, 469-475.

WillCox, M. D. P. \& DrUCKer, D. B. (1989). Surface structures, coaggregation and adherence phenomena of Streptococcus oralis and related species. Microbios 59, 19-29.

Willcox, M. D. P. \& KNox, K. W. (1990). Surface-associated properties of Streptococcus milleri group strains and their potential relation to pathogenesis. Journal of Medical Microbiology 31, 259-270.

Willcox, M. D. P., GeYelin, A. J. \& KNox, K. W. (1992). The binding of fibronectin and albumin to strains within the Streptococcus milleri group. In New Perspectives on Streptococci and Streptococcal Infections (Zentralblatt für Bakteriologie suppl. 22), pp. 154-155. Edited by G. Orefici. Stuttgart: Gustav Fischer Verlag.

Williams, B. L., McCanN, G. F. \& SchoenkneCht, F. D. (1983) Bacteriology of dental abscesses of endodontic origin. Journal of Clinical Microbiology 18, 770-774.

Wyatt, J. E., Willcox, M. D. P., Russell, R. R. B. \& Handley, P. S. (1988). Fibrillar strains of Streptococcus sanguis biotype I carry a surface protein which cross-reacts with antigen B from Streptococcus mutans Ingbritt. Oral Microbiology and Immunology 3, 162-168. 